\title{
Robiginitalea myxolifaciens sp. nov., a novel myxol-producing bacterium isolated from marine sediment, and emended description of the genus Robiginitalea
}

Correspondence

Hiroaki Kasai

hkasai@kitasato-u.ac.jp

\author{
Hao Do Manh,† Yoshihide Matsuo, Atsuko Katsuta, Satoru Matsuda, \\ Yoshikazu Shizuri and Hiroaki Kasai
}

Marine Biotechnology Institute, 3-75-1 Heita, Kamaishi, Iwate 026-0001, Japan

\begin{abstract}
A marine, Gram-negative, deep-orange-coloured, rod/coccoid-shaped, strictly aerobic, nonmotile, oxidase- and catalase-positive bacterial strain, designated $\mathrm{YM}^{\mathrm{M}}-073^{\top}$, was isolated from sediment collected in Okinawa, Japan. Strain YM6-073 ${ }^{\top}$ produced the carotenoid $\left(3 R, 2^{\prime} S\right)$ myxol. A phylogenetic analysis based on 16S rRNA gene sequences revealed that strain YM6$073^{\top}$ belonged to a distinct lineage in the family Flavobacteriaceae, the closest relative being

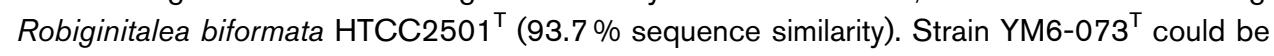
distinguished from other members of the family Flavobacteriaceae by means of a number of phenotypic characteristics. The DNA G $+\mathrm{C}$ content was $50.1 \mathrm{~mol} \%$. The predominant cellular fatty acids were iso- $\mathrm{C}_{15: 0}$, iso- $\mathrm{C}_{15: 1} \omega 10 \mathrm{c}$, iso- $\mathrm{C}_{17: 0} 3-\mathrm{OH}$ and $\mathrm{C}_{15: 0 \text {, and menaquinone- } 6 \text { was }}$ the only respiratory quinone. DNA-DNA hybridization between strain $\mathrm{YM}^{\mathrm{M}}-073^{\top}$ and $R$. biformata DSM $15991^{\top}$ showed less than $10 \%$ DNA-DNA relatedness. On the basis of phenotypic, genotypic and phylogenetic features, strain $\mathrm{YM} 6-073^{\top}$ represents a novel species of the genus Robiginitalea, for which the name Robiginitalea myxolifaciens sp. nov. is proposed. The type strain is $\mathrm{YM}^{-073^{\top}}\left(=\mathrm{MBIC} 06409^{\top}=\mathrm{KCTC} 22216^{\top}=\mathrm{DSM} 21019^{\top}\right)$.
\end{abstract}


(Eclipse E600; Nikon) examination of a $48 \mathrm{~h} \mathrm{MB}$ culture. Gliding motility was observed by using the same method, according to the minimal standards for describing novel taxa in the family Flavobacteriaceae (Bernardet et al., 2002). Oxidase activity was tested using oxidase test paper (Eiken). Catalase activity was tested using a $3 \% \mathrm{H}_{2} \mathrm{O}_{2}$ solution. Degradation of alginate $(1 \%, \mathrm{w} / \mathrm{v})$, agar $(1.5 \%$, $\mathrm{w} / \mathrm{v})$, aesculin $(0.1 \%, \mathrm{w} / \mathrm{v})$, starch $(0.2 \%, \mathrm{w} / \mathrm{v})$, casein $(2 \%, \mathrm{w} / \mathrm{v})$, gelatin $(1 \%, \mathrm{w} / \mathrm{v})$, cellulose (carboxymethylcellulose at $1 \%, \mathrm{w} / \mathrm{v}$, and filter paper), chitin $(1 \%, \mathrm{w} / \mathrm{v})$, DNA $(0.4 \%, w / v)$ and urea $(2 \%, w / v)$ were determined according to the methods of Smibert \& Krieg (1994). Chitinase activity was tested by using the plate method of O’Brien \& Colwell (1987). Other biochemical characteristics were examined by using the API 20NE commercial system (bioMérieux) incubated at $30{ }^{\circ} \mathrm{C}$ for $24 \mathrm{~h}$. For the determination of nutritional features, strain YM6- $073^{\mathrm{T}}$ was grown on $\mathrm{MA}$ at $30{ }^{\circ} \mathrm{C}$ for $72 \mathrm{~h}$ and suspended in a basal medium that consisted of artificial seawater (Tropic Marin) containing $0.01 \%$ yeast extract (Difco). A $20 \mu \mathrm{l}$ aliquot of the suspension was transferred to each well of a 96-well plate containing $500 \mu \mathrm{l}$ basal medium supplemented with various carbon sources at $0.2 \%$. Plates were incubated at $30{ }^{\circ} \mathrm{C}$ for 1 week on a Küner orbital shaker (300 r.p.m.). Susceptibility to antibiotics was examined as described by Ivanova et al. (2001).

Phenotypic properties of YM6- $073^{\mathrm{T}}$ are given in the species description, while those characteristics that serve to differentiate the strain from Robiginitalea biformata DSM $15991^{\mathrm{T}}$ are listed in Table 1. No flexirubin-type pigments could be detected with the simple $\mathrm{KOH}$ test detailed in the

Table 1. Differential characteristics of strain $Y M 6-073^{\top}$ with respect to $R$. biformata DSM $15991^{\top}$

Strains: 1, YM6-073 ${ }^{\mathrm{T}}$ (this study); 2, R. biformata DSM $15991^{\mathrm{T}}$ (Cho \& Giovannoni, 2004). +, Positive; -, negative.

\begin{tabular}{|lcc|}
\hline Characteristic & $\mathbf{1}$ & $\mathbf{2}$ \\
\hline Pigmentation & Deep orange & Orange \\
Growth at/with: & - & \\
$10{ }^{\circ} \mathrm{C}$ & - & + \\
$0.25 \% \mathrm{NaC} 1$ & - & + \\
$8 \% \mathrm{NaC} 1$ & & \\
Susceptibility to: & - & + \\
Nalidixic acid & + & - \\
Streptomycin & + & - \\
Degradation of aesculin & & - \\
Utilization of: & + & - \\
D-Galactose & + & + \\
Glycerol & + & + \\
D-Sorbitol & - & + \\
L-Glutamate & - & $55-56$ \\
L-Serine & - & \\
Sodium succinate & 50.1 & \\
DNA G+C content $(\mathrm{mol} \%)$ & & \\
\end{tabular}

minimal standards for describing novel taxa of the family Flavobacteriaceae (Bernardet et al., 2002). The deeporange-coloured pigment of strain $\mathrm{YM} 6-073^{\mathrm{T}}$ has been identified as a mixture of carotenoids, among which $\left(3 R, 3^{\prime} R\right)$-zeaxanthin and $\left(3 R, 2^{\prime} S\right)$-myxol were predominant (Shindo et al., 2007). The respiratory quinone system and the cellular fatty acid composition were determined by using LC-MS as described previously (Katsuta et al., 2005). For direct comparisons, the fatty acid composition and respiratory quinone content of $R$. biformata DSM $15991^{\mathrm{T}}$ were determined in parallel. For both strain YM6- $073^{\mathrm{T}}$ and R. biformata DSM $15991^{\mathrm{T}}$, MK-6 was found to be the only respiratory quinone. The predominant cellular fatty acids in strain YM6- $073^{\mathrm{T}}$ were iso- $\mathrm{C}_{15: 0}(34.9 \%)$, iso- $\mathrm{C}_{15: 1} \omega 10 c$ $(29.8 \%)$, iso- $\mathrm{C}_{17: 0} 3-\mathrm{OH}(17.8 \%)$ and $\mathrm{C}_{15: 0}(9.5 \%)$, constituting $92.0 \%$ of the total fatty acid content. The fatty acid profile of $R$. biformata DSM $15991^{\mathrm{T}}$ was very similar (Table 2).

The genomic DNA of strain YM6- $073^{\mathrm{T}}$ was extracted by using a Wizard genomic DNA purification kit (Promega) from cells grown in $\mathrm{MB}$. The DNA G+C content was determined using the HPLC method of Mesbah \& Whitman (1989) and was found to be $50.1 \mathrm{~mol} \%$.

A 1465 bp fragment of the 16S rRNA gene was amplified from the extracted DNA by using a bacterial universal primer pair, 27F and 1492R, (Escherichia coli numbering system; Weisburg et al., 1991) specific to the 16S rRNA gene. To ascertain the phylogenetic position of strain YM6$073^{\mathrm{T}}$, the $16 \mathrm{~S}$ rRNA gene sequence was compared with related sequences obtained from Ribosomal Database Project II (Cole et al., 2007). A neighbour-joining phylogenetic tree was constructed by using MEGA, version

Table 2. Fatty acid profiles of strain $\mathrm{YM6}-073^{\top}$ and $R$. biformata DSM $15991^{\top}$

Strains: 1 , YM6- $073^{\mathrm{T}} ; 2$, R. biformata DSM $15991^{\mathrm{T}}$. All data are from this study. Data are reported as percentages of the total fatty acids. Fatty acids amounting to less than $1 \%$ in both species are not listed. ND, Not detected.

\begin{tabular}{|lcc|}
\hline Fatty acid & $\mathbf{1}$ & $\mathbf{2}$ \\
\hline Saturated & & \\
$\mathrm{C}_{15: 0}$ & 9.5 & 10.5 \\
Branched saturated & & \\
iso- $\mathrm{C}_{15: 0}$ & 34.9 & 35.3 \\
anteiso- $\mathrm{C}_{15: 0}$ & $\mathrm{ND}$ & 4.3 \\
Monounsaturated & & \\
$\mathrm{C}_{15: 1}$ & $\mathrm{ND}$ & 1.4 \\
$\mathrm{C}_{16: 1} \omega 7 c$ & 2.0 & 2.1 \\
Branched monounsaturated & & \\
iso- $\mathrm{C}_{15: 1} \omega 10 c$ & 29.8 & 25.8 \\
iso- $\mathrm{C}_{17: 1}$ & 1.6 & $\mathrm{ND}$ \\
Hydroxy & & \\
iso- $\mathrm{C}_{15: 0} 3-\mathrm{OH}$ & 3.2 & 2.5 \\
iso- $\mathrm{C}_{17: 0} 3-\mathrm{OH}$ & 17.8 & 16.0 \\
\hline
\end{tabular}


3.1 (Kumar et al., 2004). The tree topology was estimated by means of a bootstrap analysis (Felsenstein, 1993) with 1000 resamplings of the dataset. Strain YM6- $073^{\mathrm{T}}$ showed the highest 16S rRNA gene sequence similarity (93.7\%) with the type strain of $R$. biformata and showed 89.0$91.6 \%$ similarity with respect to members of the genera Arenibacter, Costertonia, Flagellimonas, Maribacter, Muricauda, Zeaxanthinibacter and Zobellia (Fig. 1). A tree based on the maximum-likelihood method and constructed using PhyML (Guindon et al., 2005) showed essentially the same topology (data not shown). Strain YM6- $073^{\mathrm{T}}$ also showed $93.6-94.9 \%$ sequence similarity with respect to several uncultured organisms and environmental clones from marine sediment (see Supplementary Fig. S1 available in IJSEM Online).
DNA-DNA hybridization between strain YM6- $073^{\mathrm{T}}$ and $R$. biformata DSM $15991^{\mathrm{T}}$ was performed with photobiotinlabelled probes in microplate wells as described by Ezaki et al. (1989) with five replications. The temperature was set at $44.7^{\circ} \mathrm{C}$. The highest and lowest values obtained were excluded and the mean of the remaining three values was quoted as the DNA-DNA relatedness value. Strain YM6$073^{\mathrm{T}}$ and R. biformata DSM $15991^{\mathrm{T}}$ shared approximately $8.5 \%$ DNA-DNA relatedness.

On the basis of the results of the 16S rRNA gene sequencebased phylogenetic analysis and the above-mentioned phenotypic data, strain $\mathrm{YM} 6-073^{\mathrm{T}}$ represents a novel species within the genus Robiginitalea, for which the name Robiginitalea myxolifaciens sp. nov. is proposed. Additional

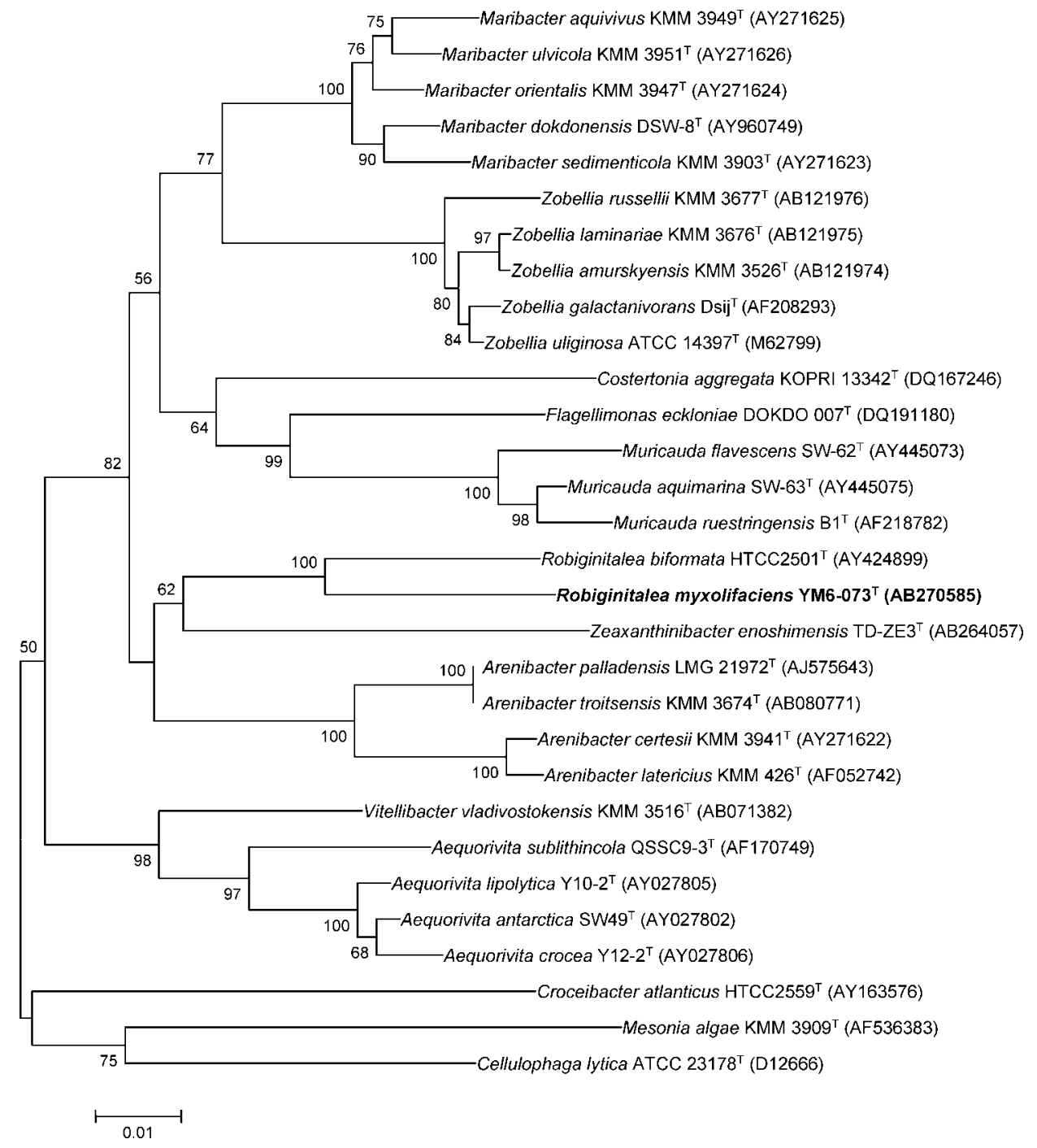

Fig. 1. Unrooted neighbour-joining phylogenetic tree based on the $16 \mathrm{~S}$ rRNA gene sequences of strain $\mathrm{YM}^{\mathrm{N}-073^{\top} \text { and }}$ representative members of related genera in the family Flavobacteriaceae. Only bootstrap percentages greater than $50 \%$ (based on 1000 replications) are indicated at nodes. GenBank accession numbers are shown in parentheses. Bar, 0.01 substitutions per nucleotide position. 
data obtained in this study also make emendation of the genus description necessary.

\section{Emended description of the genus Robiginitalea Cho \& Giovannoni 2004}

The description of the genus is as given by Cho \& Giovannoni (2004), with the following amendments. MK-6 is the only respiratory quinone. The predominant fatty acids are iso- $\mathrm{C}_{15: 0}$, iso- $\mathrm{C}_{15: 1} \omega 10 c$, iso- $\mathrm{C}_{17: 0} 3-\mathrm{OH}$ and $\mathrm{C}_{15: 0}$. The DNA G+C content is $50-56 \mathrm{~mol} \%$.

\section{Description of Robiginitalea myxolifaciens sp. nov.}

Robiginitalea myxolifaciens [my.xo.li.fa'ci.ens. N.L. n. myxol -olis myxol; L. part. adj. faciens (from L. v. facio) producing; N.L. part. adj. myxolifaciens myxol-producing].

Cells are straight rods $(0.9-3.5 \mu \mathrm{m}$ long and $0.3-0.65 \mu \mathrm{m}$ wide) during the exponential growth phase and coccoid $(0.48-1.30 \mu \mathrm{m}$ in diameter) in the stationary phase and are devoid of flagellar and gliding motility. Gram-negative. Colonies on 1/10-strength MA are rhizoid, convex and deep orange in colour. Carotenoid pigments are produced, but flexirubin pigments are not produced. Obligatory aerobic and chemoheterotrophic. Growth occurs at 15.0$42.0{ }^{\circ} \mathrm{C}$ (optimally at $30.0{ }^{\circ} \mathrm{C}$ ) and at $\mathrm{pH}$ 6.5-9.5 (optimally at $\mathrm{pH}$ 7.6-8.5). Optimal growth occurs in the presence of 3-4\% (w/v) NaCl; growth is inhibited in the absence of $\mathrm{NaCl}$ and in the presence of $>7 \%(\mathrm{w} / \mathrm{v}) \mathrm{NaCl}$. Nitrate is not reduced. Oxidase, catalase and $\beta$-galactosidase activities are present. Glucose, galactose, maltose, sucrose, fructose, raffinose, sorbitol, trehalose, mannose, lactose, cellobiose, sorbose, melibiose, ornithine monohydrochloride and glycerol are utilized as sole carbon sources, but rhamnose, ethanol, lysine, serine, isoleucine, leucine, glycine, glutamate, sodium citrate, sodium lactate, sodium succinate, sodium pyruvate, sodium gluconate and itaconic acid are not. Starch and aesculin are hydrolysed, but gelatin, DNA, carboxymethylcellulose, crystalline cellulose (filter paper), urea, chitin, agar, casein and alginate are not. Benzylpenicillin, rifampicin, erythromycin and tetracycline affect growth, but nalidixic acid, kanamycin, gentamicin and cycloheximide do not. The predominant cellular fatty acids $(>9 \%)$ are iso- $\mathrm{C}_{15: 0}$, iso- $\mathrm{C}_{15: 1} \omega 10 c$, iso- $\mathrm{C}_{17: 0} 3-\mathrm{OH}$ and $\mathrm{C}_{15: 0}$. The DNA $\mathrm{G}+\mathrm{C}$ content of the type strain $\left(\mathrm{YM} 6-073^{\mathrm{T}}\right.$ ) is $50.1 \mathrm{~mol} \%$ (HPLC method).

The type strain, YM6-073 ${ }^{\mathrm{T}} \quad\left(=\mathrm{MBIC} \quad 06409^{\mathrm{T}}=\mathrm{KCTC}\right.$ $22216^{\mathrm{T}}=$ DSM $21019^{\mathrm{T}}$ ), was isolated from marine sediment in Okinawa, Japan.

\section{Acknowledgements}

We thank Dr J. Euzéby for his recommendations about etymology and we are grateful to Dr K. Adachi for her help with chemotaxonomic analyses. We appreciate the technical assistance of Yukiko Itazawa, Ayako Matsuzaki and Tomomi Haga. This research was supported by the New Energy and Industrial Technology
Development Organization (NEDO) and the Japan International Cooperation Agency (JICA).

\section{References}

Bernardet, J.-F. \& Nakagawa, Y. (2006). An introduction to the family Flavobacteriaceae. In The Prokaryotes, a Handbook on the Biology of Bacteria, 3rd edn, vol. 7, pp. 455-480. Edited by M. Dworkin, S. Falkow, E. Rosenberg, K.-H. Schleifer \& E. Stackebrandt. New York: Springer.

Bernardet, J.-F., Nakagawa, Y. \& Holmes, B. (2002). Proposed minimal standards for describing new taxa of the family Flavobacteriaceae and emended description of the family. Int J Syst Evol Microbiol 52, 1049-1070.

Bowman, J. P. (2006). The marine clade of the family Flavobacteriaceae: the genera Aequorivita, Arenibacter, Cellulophaga, Croceibacter, Formosa, Gelidibacter, Gillisia, Maribacter, Mesonia, Muricauda, Polaribacter, Psychroflexus, Psychroserpens, Robiginitalea, Salegentibacter, Tenacibaculum, Ulvibacter, Vitellibacter, and Zobellia. In The Prokaryotes, a Handbook on the Biology of Bacteria, 3rd edn, vol. 7, pp. 677-694. Edited by M. Dworkin, S. Falkow, E. Rosenberg, K.-H. Schleifer \& E. Stackebrandt. New York: Springer.

Cho, J.-C. \& Giovannoni, S. J. (2004). Robiginitalea biformata gen. nov., sp. nov., a novel marine bacterium in the family Flavobacteriaceae with a higher $\mathrm{G}+\mathrm{C}$ content. Int $J$ Syst Evol Microbiol 54, 1101-1106.

Cole, J. R., Chai, B., Farris, R. J., Wang, Q., Kulam-Syed-Mohideen, A. S., McGarrell, D. M., Bandela, A. M., Cardenas, E., Garrity, G. M., Tiedje, J. M. \& other authors (2007). The ribosomal database project (RDP-II): introducing myRDP space and quality controlled public data. Nucleic Acids Res 35 (Database issue), D169-D172.

Ezaki, T., Hashimoto, Y. \& Yabuuchi, E. (1989). Fluorometric deoxyribonucleic acid-deoxyribonucleic acid hybridization in microdilution wells as an alternative to membrane filter hybridization in which radioisotopes are used to determine genetic relatedness among bacterial strains. Int J Syst Bacteriol 39, 224-229.

Felsenstein, J. (1993). PHYLIP (phylogeny inference package), version 3.5. Distributed by the author. Department of Genome Sciences, University of Washington, Seattle, USA.

Garrity, G. M. \& Holt, J. G. (2001). The road map to the Manual. In Bergey's Manual of Systematic Bacteriology, 2nd edn, vol. 1, pp. 119-166. Edited by D. R. Boone, R. W. Castenholz \& G. M. Garrity. New York: Springer.

Guindon, S., Lethiec, F., Duroux, P. \& Gascuel, O. (2005). PHYML Online-a web server for fast maximum likelihood-based phylogenetic inference. Nucleic Acids Res 33 (Web Server issue), W557-W559.

Ivanova, E. P., Nedashkovskaya, O. I., Chun, J., Lysenko, A. M., Frolova, G. M., Svetashev, V. I., Vysotskii, M. V., Mikhailov, V. V., Huq, A. \& Colwell, R. R. (2001). Arenibacter gen. nov., new genus of the family Flavobacteriaceae and description of a new species, Arenibacter latericius sp. nov. Int J Syst Evol Microbiol 51, 1987-1995.

Katsuta, A., Adachi, K., Matsuda, S., Shizuri, Y. \& Kasai, H. (2005). Ferrimonas marina sp. nov. Int J Syst Evol Microbiol 55, 1851-1855.

Kumar, S., Tamura, K. \& Nei, M. (2004). MEGA3: integrated software for molecular evolutionary genetics analysis and sequence alignment. Brief Bioinform 5, 150-163.

Llobet-Brossa, E., Rosselló-Mora, R. \& Amann, R. (1998). Microbial community composition of Wadden Sea sediments as revealed by fluorescence in situ hybridization. Appl Environ Microbiol 64, 2691-2696.

Mesbah, M. \& Whitman, W. B. (1989). Measurement of deoxyguanosine/thymidine ratios in complex mixtures by high-performance liquid chromatography for determination of the mole percentage guanine + cytosine of DNA. J Chromatogr 479, 297-306. 
Murray, R. G. E., Doetsch, R. N. \& Robinow, F. (1994). Determinative and cytological light microscopy. In Methods for General and Molecular Bacteriology, pp. 21-41. Edited by P. Gerhardt, R. G. E. Murray, W. A. Wood \& N. R. Krieg. Washington, DC: American Society for Microbiology.

O’Brien, M. \& Colwell, R. R. (1987). A rapid test for chitinase activity that uses 4-methylumbelliferyl- $N$-acetyl- $\beta$-D-glucosaminide. Appl Environ Microbiol 53, 1718-1720.

Shindo, K., Kikuta, K., Suzuki, A., Katsuta, A., Kasai, H., YasumotoHirose, M., Matsuo, Y., Misawa, N. \& Takaichi, S. (2007). Rare carotenoids, $(3 R)$-saproxanthin and $\left(3 R, 2^{\prime} S\right)$-myxol, isolated from novel marine bacteria (Flavobacteriaceae) and their antioxidative activities. Appl Microbiol Biotechnol 74, 1350-1357.

Smibert, R. M. \& Krieg, N. R. (1994). Phenotypic characterization. In Methods for General and Molecular Bacteriology, pp. 607-654. Edited by P. Gerhardt, R. G. E. Murray, W. A. Wood \& N. R. Krieg. Washington, DC: American Society for Microbiology.

Weisburg, W. G., Barns, S. M., Pelletier, D. A. \& Lane, D. J. (1991). $16 \mathrm{~S}$ ribosomal DNA amplification for phylogenetic study. J Bacteriol 173, 697-703. 